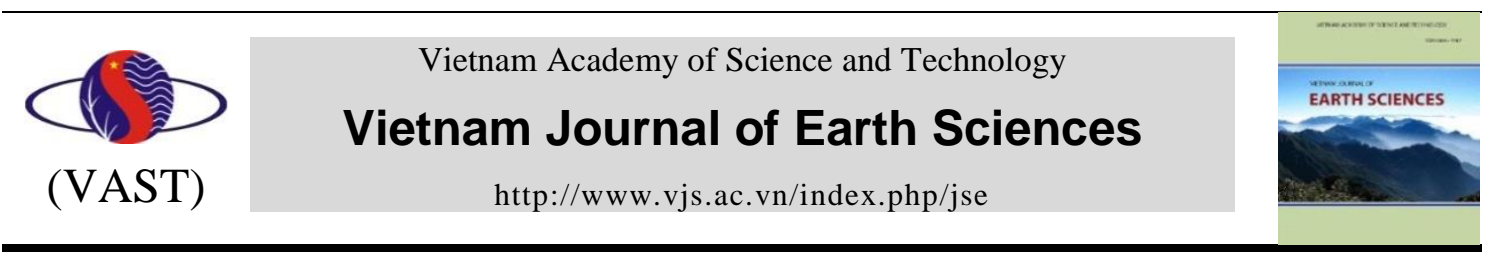

\title{
Occurrence of supergene nickel ores in the Ha Tri Massive, Hoa An District, Cao Bang Province
}

\author{
Nguyen Van Pho ${ }^{* 1}$, Pham Tich Xuan ${ }^{1}$, Pham Thanh Dang ${ }^{1,2}$ \\ ${ }^{1}$ Institute of Geological Sciences, VAST \\ ${ }^{2}$ Graduate University of Science and Technology, VAST
}

Received 27 July 2017; Received in revised form 25 January 2018; Accepted 8 February 2018

\begin{abstract}
Nickel (Ni) laterites are regolith materials derived from ultramafic rocks and play an important role in the world's $\mathrm{Ni}$ production. Ni-laterite deposits are the supergene enrichment of $\mathrm{Ni}$ formed from the intense chemical and mechanical weathering of ultramafic parental rocks. In Vietnam, the weathering profile containing Ni laterite was first discovered in the Ha Tri massive (Cao Bang). This profile develops on the Ha Tri serpentinized peridotite rocks classified to the Cao Bang mafic-ultramafic complex (North Vietnam) and exhibits thick weathered zone (10-15m). This work carried out a detailed study of the weathering profile at the center of Ha Tri massive. Samples from different horizons of the profile were collected and analyzed in detail by XRF, XRD and SEM-EDX methods to establish the relationship between the Ni-rich supergene products and the parental peridotites (lherzolite) rocks in Ha Tri massive. The results show that the saprolite horizon is most Ni-rich in the weathering profile in Ha Tri. In this horizon, Nisilicate minerals of garnierite group such as pimelite, nepouite and other $\mathrm{Mg}-\mathrm{Ni}$ silicates have been found. The appearance of minerals of garnierite group is due to the exchange of $\mathrm{Mg}$ by Ni during weathering of peridotite minerals, especially olivine, which leads to the enrichment of the supergene Ni. The occurrence of Ni silicates suggests the existence of the supergene $\mathrm{Ni}$ ore in the weathering profile of the Ha Tri massive.
\end{abstract}

Keywords: Supergene nickel ore; weathering profile; Ha Tri peridotites; garnierite; Ni-enriched clay minerals.

C2018 Vietnam Academy of Science and Technology

\section{Introduction}

Nickel laterites are regolith materials derived from ultramafic rocks, such as peridotites (Trescases, 1975; Golightly, 1981; Brandet al., 1998). Weathering of the rocks results in enriched horizons so that minor elements such as $\mathrm{Ni}, \mathrm{Co}$, and $\mathrm{Mn}$ contained in the unaltered parent rock become enriched in

"Corresponding author, Email: phodiahoa43@gmail.com the laterite profiles (Brand et al., 1998; Freyssinet et al., 2005; Golightly, 2010). Nowadays, nickel laterites become an important resource of nickel and ferronickel and account for approximately $40 \%$ of world annual nickel production (Gleeson et al., 2003). Of the 130 million tonnes (Mt) of nickel in land-based resources containing over $1 \%$ nickel, approximately $60 \%$ is in laterite deposits (USGS Mineral Commodity Summary, 
2002). These deposits are produced by the prolonged and deep weathering of ultramafic rocks, such as peridotite, generally in humid tropical to subtropical climates. As a consequence, many recently formed and actively forming deposits are situated in equatorial latitudes, where major producing countries of nickel laterite ores are located (e.g, New Caledonia, Cuba, Philippines, Indonesia, Colombia, and Australia). Studies on nickel deposits coupled with chemical analyses have been widely documented (Colin et al., 1990, Golightly, 1981 and Pelletier, 1996). During weathering, some elements become leached (e.g, magnesium, calcium and silicon) and others either are secondarily enriched (e.g, nickel, manganese, zinc and yttrium) or residually concentrates (e.g, iron, chromium, aluminum, titanium and zirconium) within laterite profiles (Brand et al., 1998).

Vietnam locates in the humid tropical zone and the territory has some ultramafic intrusions, but previously there was little information on the presence of nickel laterite (Nguyen Van Pho, 2013); only recently discovered epigenetic nickel in weathering crust in Ha Tri peridotites, Cao Bang complex. The typical profile exposed in the open pit was studied and detailed examinations were performed on the vertical profile. Field descriptions were supplemented with the study of oriented samples by optical microscopy, Xray diffraction (XRD), and scanning electron microscope (SEM). The most Ni-rich smectites were studied by extended X-ray absorption fine-structure spectroscopy (EXAF). The results of this study are discussed in this paper.

\section{Geological setting}

Ha Tri is a northeastern massif in the chain of mafic-ultramafic massifs in the Cao Bang complex (Figure 1), that trends NW-SE about
$40 \mathrm{~km}$ in length and intrudes Permian-Triassic and Triassic volcanic-sedimentary sequence of the Song Hien Formation (Hoa et al., 2008a,b; Hoang et al., 2010; Tri and Khuc, 2011).

Like other massifs in the Cao Bang complex, Ha Tri massif consists mainly of the mafic-ultramafic unit which is composed of lherzolite, and websterite olivine melanogabbro, plagioclase-bearing wehrlite and gabbronorite, and the mafic unit which is composed of olivine-free dolerite and leucogabbro. The plagioclase-bearing lherzolite is located in the central part of the intrusion, and the melanogabbro is confined to its marginal areas. The plagioclase-bearing wehrlite is less abundant that forms a quenched contact zone between the olivine melanogabbro and the country rocks. The gabbronorite occurs as dykes cutting the plagioclase-bearing lherzolite (Hoa T.T et al., 2008a,b). The studied profile is located in weathering core in the ultramafic part of Ha Tri massif, consisting predominantly plagioclase bearing lherzolite and lesser websterite. The rocks are usually grey, dark grey, sometimes grayish green. A detailed description of the mafic and ultramafic rocks of Cao Bang complex can be found in Thanh (2014) and Svetliskaya (2016). Plagioclase- bearing lherzolite comprises of olivine ranged from 40 to $70 \%$ or more, clinopyroxene (15-20\%), orthopyroxene (a few percent), plagioclase (up to $10 \%$ ). Cr- spinel and reddish-brown phlogopite are common as accessory minerals. Ore minerals such as magnetite, ilmenite, and sulfides (pyrite, pyrrhotite, chalcopyrite) are common in the rocks. Secondary minerals are hornblende, chlorite and serpentine. Olivine usually is strongly serpentinized, many olivine crystals are completely serpentinized. The rocks are characterized by the subhedral structure with euhedral olivine and anhedral pyroxene crystals. 
Vietnam Journal of Earth Sciences, 40(2), 153-164

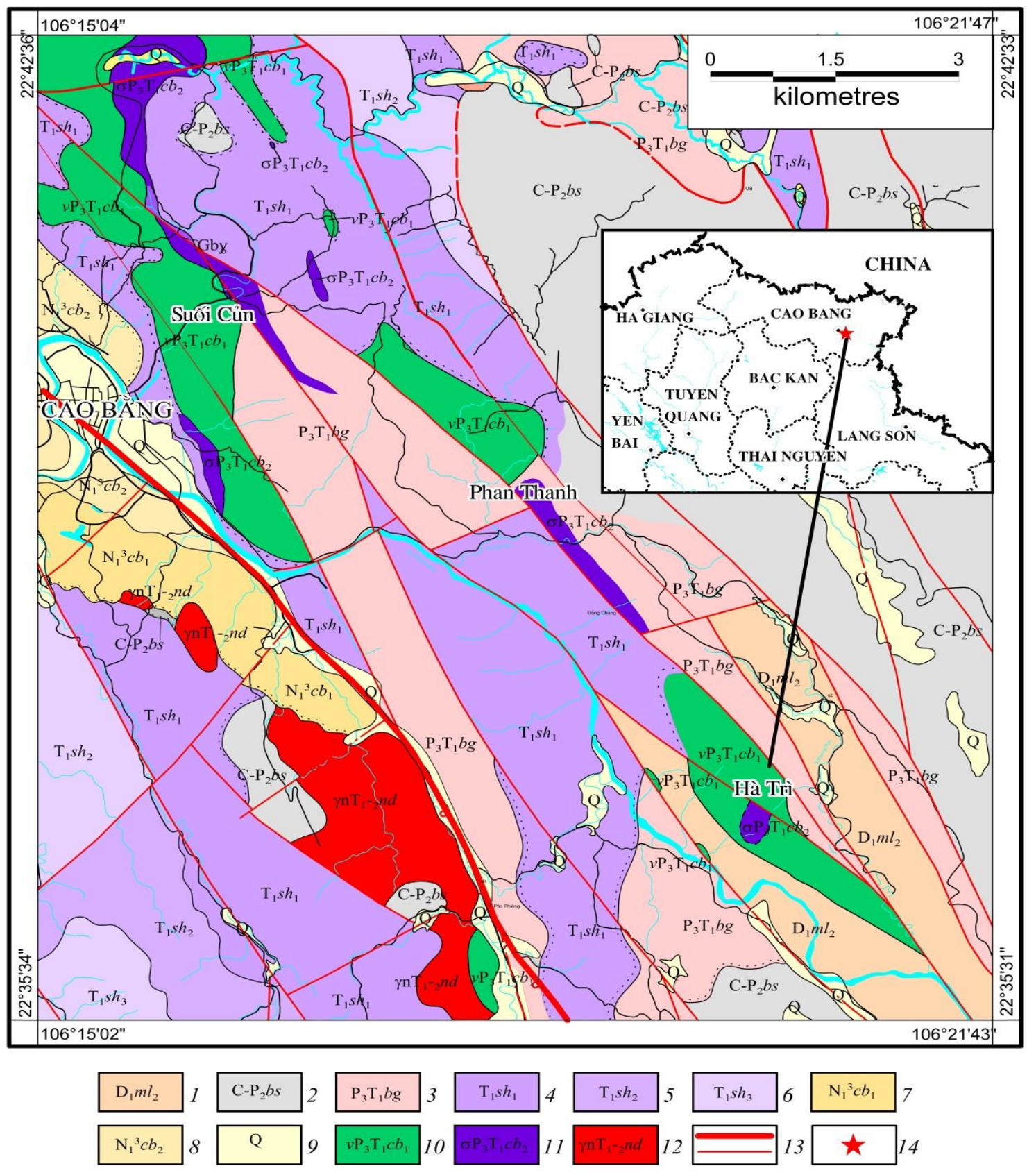

Figure 1. Geological map of Ha Tri-Suoi Cun area, Cao Bang province. 1. Mia Le Formation (D1ml); 2. Bac Son Formation (C-P2bs); 3. Bang Giang Formation (P3-T1bg); 4, 5, 6. Song Hien Formation: 4. Sub-formation (Strata) 1 (T1sh1), 5. Sub-formation (Strata) 2 (T1sh2), 6. Sub-formation (Strata) 3 (T1sh3); 7, 8. Cao Bang Formation: 7. Subformation (Strata) 1 (N13cb1), 8. Sub-formation (Strata) 2 (N13cb2); 9. Quaternary sediments; 10, 11. Maficultramafics Cao Bang Complex: 10. Phase 1 (vP3T1cb1), 11. Phase 2 ( $\sigma$ P3T1cb2); 12. Granite Nui Dieng Complex ( $\gamma \mathrm{nT1}$-2nd); 13. Tectonic faults; 14. Location of study area. (modified from Geological maps of sacle 1:50000, Trung Khanh lists (Nguyen Cong Thuan, et al. 2005) and Cao Bang - Dong Khe lists (Nguyen The Cuong, 2000)) 
Nguyen Van Pho, et al./Vietnam Journal of Earth Sciences 40 (2018)

\section{Material and Methods}

\subsection{Field observation}

Weathering profile in the open pit at $\mathrm{Ha}$ Tri varies in thickness and continuity for individual layers. Intense post-erosion processes are unlikely after lateritization in $\mathrm{Ha} \mathrm{Tri,}$ however, possibilities of erosion cannot be absolutely ruled out considering the incline geomorphology of the study area. The profile formed on almost serpentinized peridotite, that which forms the base of the profile. This profile is up to $15 \mathrm{~m}$ thick and consists of 3 main layers (Figure 2a).

At the bottom, the 2-m-thick coherent layer represents the earliest stages of weathering. Rocks in this layer vary from greenish-black to beige in color. Although the rock is coherent, it is cut by a network of cracks filled with and greenish smectite. These cracks formed along tectonically induced joints. The weath-

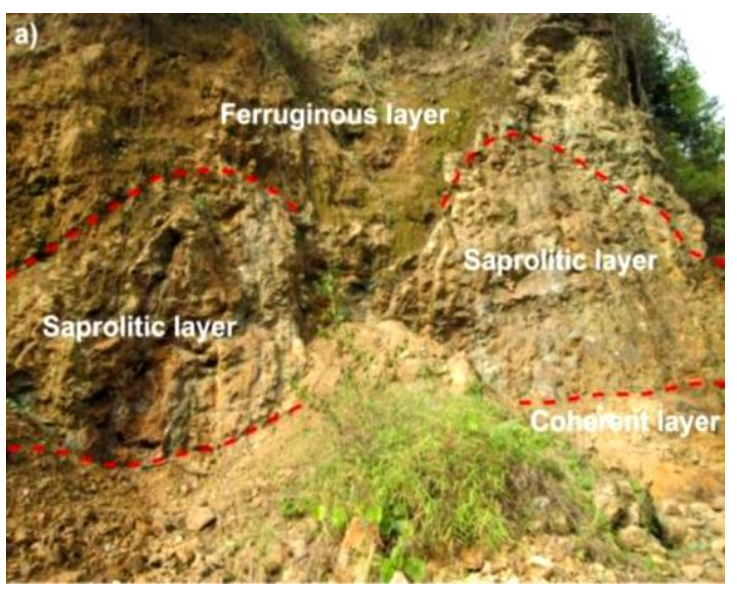

ered rock between these cracks consists of olivine and pyroxene that are partly altered to smectite. However, the smectite is not well developed except where the parent rock is strongly fractured. Because the original structures are well preserved, the weathering in this layer have been isovolumetric.

The overlying saprolitic layer develops from further weathering of the fractured bedrock. It is browner, thicker $(8 \mathrm{~m})$, and more friable than the underlying coherent layer. Also, the residual joint-bounded blocks become rounder and decrease in size upward. Between blocks, the greenish matrix is cut by centimeter- to millimeter-thick cracks that are filled with greenish materials (Figure 2b). Toward the top of this layer only a few small pieces of brownish rocks persist and are scattered in a green-brown clayey matrix and it still preserves the original rock structures.

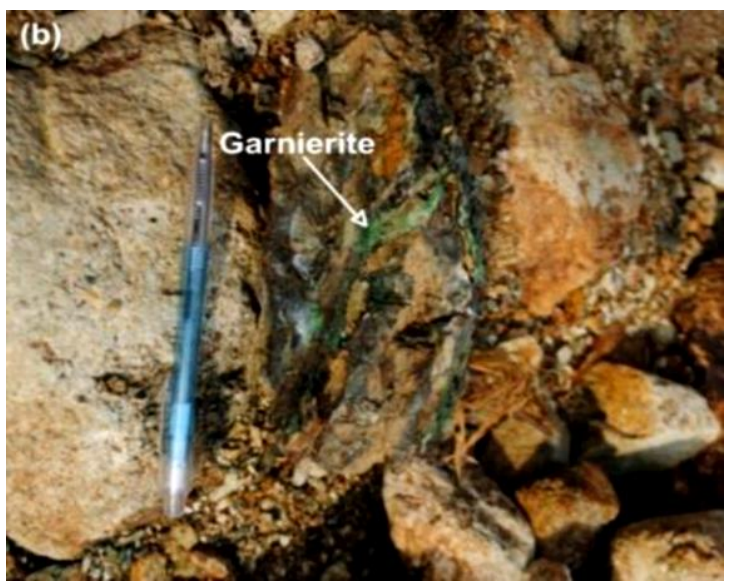

Figure 2. Weathering profile with Ni supergene mineralization (green color) in open pit wall at Ha Tri village (a), and garnierite in the filling fractures $(b)$

The clayey ferruginous layer is $4 \mathrm{~m}$ thick and consists of reddish to whitish, variegated clay-sized goethite and kaolinite. This part of the profile has been compacted so that the primary structure of the parent rock has been destroyed. The nodular layer is a 2-m-thick zone made up of a powdery red ferruginous material (goethitic nodules). Dark manganese oxide blebs or nodules are commonly observed in a top zone within the oxide matrix associated with the surface organic zone which randomly hosts visible iron crusts.

\subsection{Analytical methods}

A sampling of the lateritic profile was carried out in the wall of the open pit at Ha Tri 
location. Bulk chemical compositions of samples were determined X-ray fluorescence (XRF) technique. The morphological properties and major elements were examined by using the scanning electron microscope (SEM) with energy dispersive X-ray spectroscopy (EDS), (FEI Quanta 450) at the Institute of Geological Sciences, VAST. Clay minerals were analyzed by X-ray diffraction (XRD). For this method, analyses were performed on oriented mounds, using an X-ray diffractometer (PANalytical - Empyrean) at room temperature, using $\mathrm{Cu} \mathrm{K} \alpha$ target with a voltage of 45 $\mathrm{kV}$ and a current of $40 \mathrm{~mA}$ at the Institute of Geological Sciences, VAST. The grain rims morphology was examined by Scanning electron microscopy (SEM), and the Ni content was determined semi-quantitatively using an energy dispersive spectrometer. Instruments used were a FEI Quanta 650, Institute of Geological Sciences, VAST, operating at 10$30 \mathrm{kV}$ accelerating voltage, $3 \times 10-12$ A primary beam current, and 9-20 mm working distance.

\section{Results and Discussion}

The XRD results for different depths of the representative profile show that the mineralogy changes according to a certain rule and that each layer has the distinct mineral association. The coherent layer has peaks for the serpentine polymorphs, amphibole, antigorite, diopside chrysotile, mica, talc and chlorite (Figure $4 c)$. In the saprolitic layer, mainly clay mineral, kaolinite, vermiculite occur; especially here appeared willemsite (hydrated silicate $\mathrm{Ni})$. Nevertheless, in this layer, relicts of serpentine and talc were still detected by XRD (Figure 3a). The ferruginous layer is soft and friable consisting goethite, kaolinite, chlorite and quarts (Figure $3 b$ ).

Compared to the basement rock mineralogy, the primary mineralogy and texture of the host rock are totally destroyed in the encrusted ferruginous zone. Goethite and kaolinite are predominant minerals alternating the primary minerals. An iron cap (ferricrete or duricrust) is often found at the top of the weathering profile and the cap grades downward through a transitional zone of limonite to a saprolite zone transitional into bedrock. Saprolite is a zone of rapid change and of maximum supergene enrichment of nickel. The protolith or bedrock is mainly peridotite, harzburgite, or lherzolite and their serpentinized equivalents. This mineralogical and chemical zonation appears common when compared to other weathering profiles of ultrabasic rocks reported in the literature (Delvigne et al., 1979; Fontanaud, 1982; Nahon \& Colin, 1982; Nahon et al., 1982a,b; Paquet et al.,1983; Colin et al., 1985, 1990).

The chemical data of the parent rock and of the layers are given in Table 1. In order to evaluate gains and losses during supergene weathering at $\mathrm{Ha}$ Tri, we choose the approach of mass balance calculations which was employed successfully by previous authors on weathered rocks (e.g. Moroni et al., 2001). The percentage gain or loss in the concentration of each element in weathered samples was compared with that of the parent rock according to the equation:

$$
\Delta \%=\left\lfloor\frac{X_{a} / I_{a}}{X_{u} / I_{u}}\right\rfloor \times 100
$$

where $\mathrm{Xa}$ and $\mathrm{Xu}$ are the element concentration in the weathered sample and the parent rock respectively. On the other hand, Ia and Iu are the concentration of an immobile element in the weathered sample and the parent rock, respectively. Applying this decisive factor and according to Nesbitt and Wilson (1992), chromium is the opted immobile element for Ha Tri samples compared to $\mathrm{TiO}_{2}$ or $\mathrm{Zr}$. The parent peridotites at Ha Tri, that lies just at the bottom of the profile are used for the mass balance calculation. The results of mass balance calculations for layers are given in Table 1. 
Nguyen Van Pho, et al./Vietnam Journal of Earth Sciences 40 (2018)
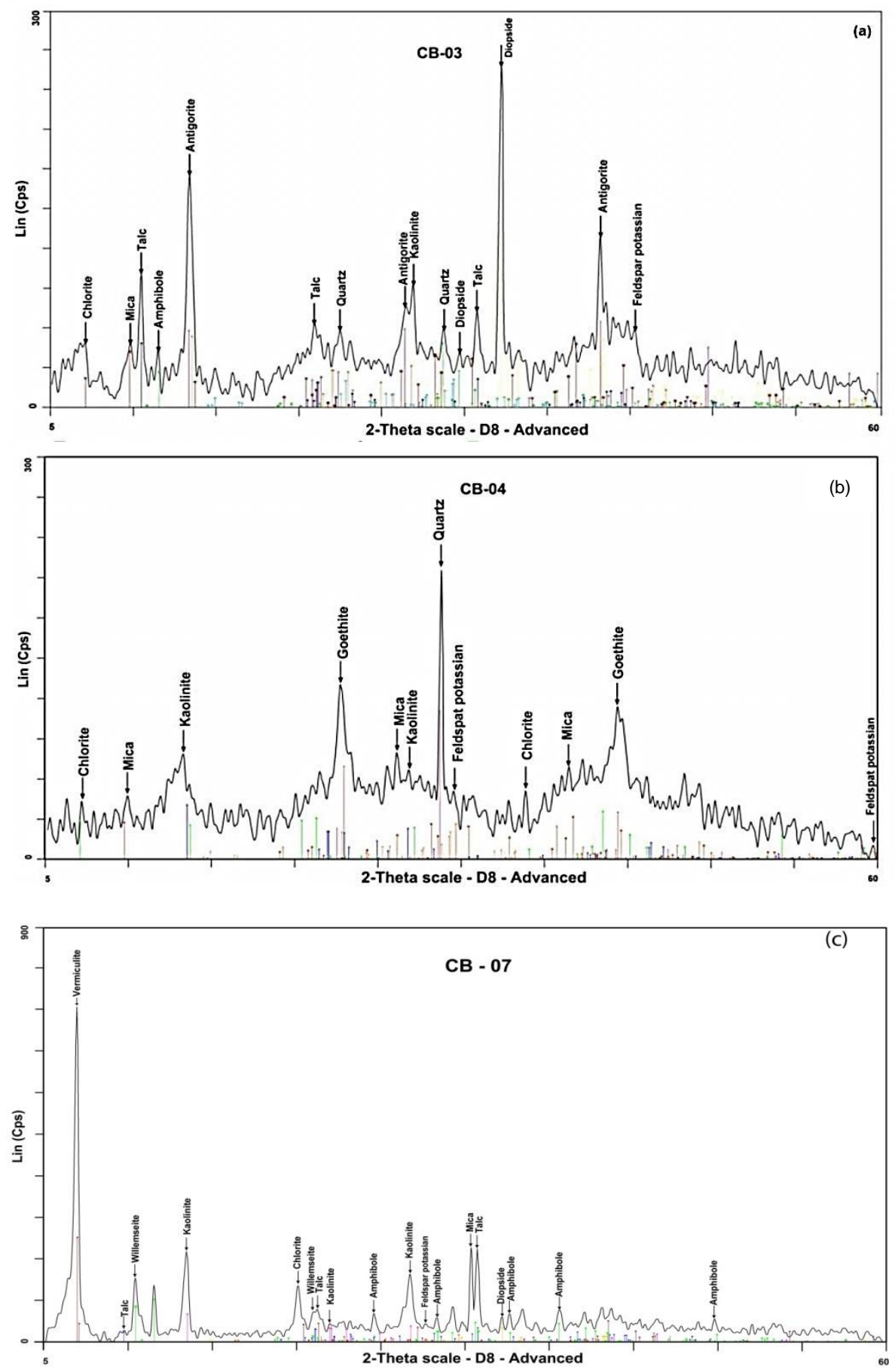

Figure 3. XRD patterns of protolith unit from Ha Tri (a) CB-03 $=10 \mathrm{~m}$, (b) CB-04 = 4m, (c) CB-07 = 8m, depth samples respectively. The spectrum was obtained using an X-ray diffractometer 'Rigaku' at room temperature, using $\mathrm{Cu}$ Ka target with a voltage of $40 \mathrm{kV}$ and a current of $20 \mathrm{~mA}$. The scan range (2q) was 2-65 with a step size of $0.02^{\circ}$ 
Vietnam Journal of Earth Sciences, 40(2), 153-164

Table 1. Bulk chemical data (wt\%) and mass balance calculations for layers of weathering profile from Ha Tri massive

\begin{tabular}{|c|c|c|c|c|c|c|c|c|c|}
\hline Layer & $\begin{array}{c}\text { Parent } \\
\text { rock }\end{array}$ & $\begin{array}{c}\text { Coherent } \\
\text { layer }\end{array}$ & $\Delta \%$ & $\begin{array}{c}\text { Saprolitic } \\
\text { Layer bottom }\end{array}$ & $\Delta \%$ & $\begin{array}{l}\text { Saprolitic } \\
\text { Layer top }\end{array}$ & $\Delta \%$ & $\begin{array}{c}\text { Ferruginous } \\
\text { layer }\end{array}$ & $\Delta \%$ \\
\hline $\mathrm{SiO}_{2}$ & 37.48 & 40.95 & -20 & 42.22 & -45 & 46.66 & -50 & 4.30 & -98 \\
\hline $\mathrm{MgO}$ & 40.60 & 26.11 & -50 & 16.16 & -60 & 3.73 & -95 & 6.50 & -90 \\
\hline $\mathrm{CaO}$ & 0.41 & 0.02 & -95 & 0.03 & -95 & 0.04 & -95 & 6.00 & -100 \\
\hline $\mathrm{Fe}_{2} \mathrm{O}_{3}$ & 8.22 & 14.46 & 30 & 9.10 & -45 & 21.55 & 0 & 72.60 & 15 \\
\hline $\mathrm{Al}_{2} \mathrm{O}_{3}$ & 0.26 & 1.49 & 230 & 6.33 & 1.075 & 1.60 & 135 & 5.67 & 190 \\
\hline $\mathrm{Cr}_{2} \mathrm{O}_{3}$ & 0.36 & 0.75 & 0 & 0.79 & -30 & 1.08 & -25 & 4.26 & 0 \\
\hline $\mathrm{MnO}_{2}$ & 0.15 & 0.25 & 25 & 0.37 & 20 & 0.47 & 20 & 0.20 & -80 \\
\hline $\mathrm{NiO}$ & 0.30 & 1.14 & 190 & 7.47 & 1.100 & 5.26 & 570 & 0.75 & -70 \\
\hline $\mathrm{CoO}$ & 0.01 & 0.02 & 50 & 0.06 & 255 & 0.81 & 1.990 & 0.02 & -70 \\
\hline $\mathrm{CuO}$ & 0.01 & 0.01 & -25 & 0.03 & 45 & 0.06 & 130 & 0.05 & -30 \\
\hline $\mathrm{H}_{2} \mathrm{O}$ & 13.78 & 12.82 & -25 & 13.74 & -50 & 17.66 & -50 & 11.70 & -90 \\
\hline
\end{tabular}

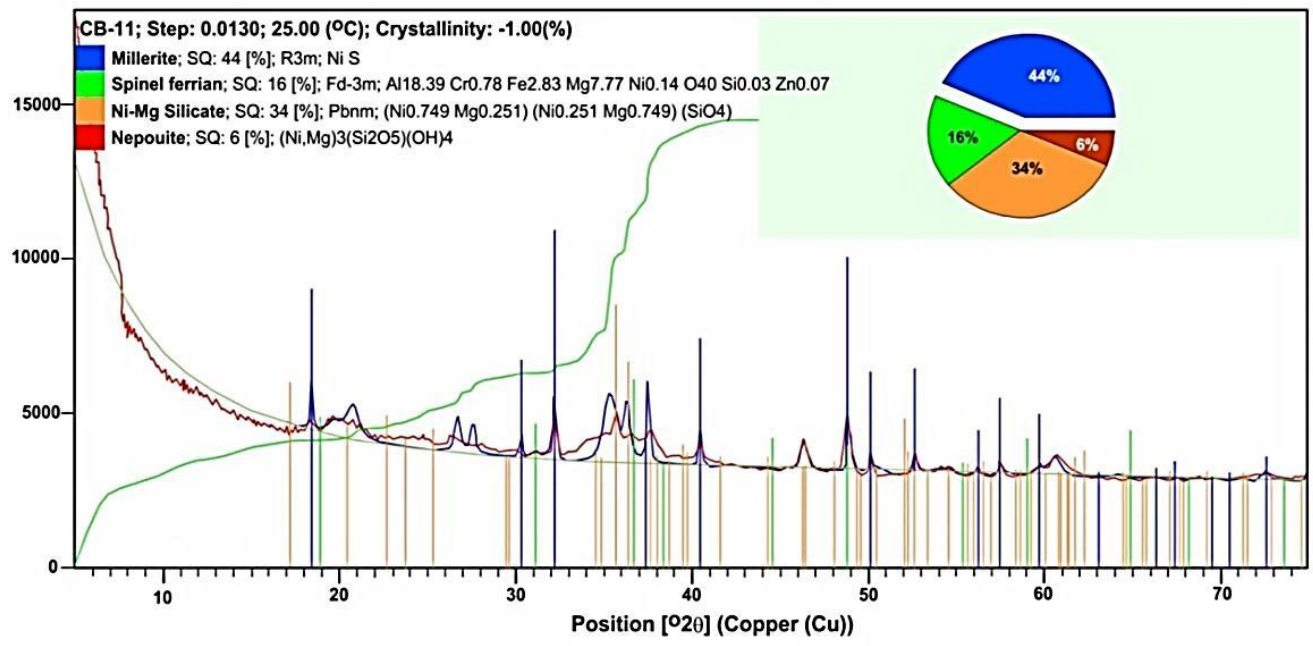

Figure 4. The XRD patterns and mineral aggregate of "garnierite" group in sample of filling fracture in saprolite horizon of weathering profile in Ha Tri

Mass balance calculations indicates that, from the serpentinized peridotite to the coherent layer about 50 percent of the $\mathrm{MgO}$ and 20 percent of the $\mathrm{SiO}_{2}$ have been removed. On the other hand, $\mathrm{NiO}$ shows an enrichment of 190 percent over the value in the parent rock. The abundances of the other elements indicate that they have been neither increased nor depleted. The saprolitic layer relative to the parent rock, 50 percent of the $\mathrm{SiO}_{2}$ and 80 to 95 percent of the $\mathrm{MgO}$ have been lost; within this layer, $\mathrm{NiO}$ shows a gain ranging from 1,100 percent (bottom) to 570 percent (top). In the clayey ferruginous layer mass balance calculations made assuming a constant content of
$\mathrm{Cr}_{2} \mathrm{O}_{3}$ indicates a gain in $\mathrm{Al}_{2} \mathrm{O}_{3}$ and a significant loss of $\mathrm{NiO}$.

Based on petrography, mineralogy and geochemistry of the parent samples studied, the schematic process affecting the peridotites which subsequently gave rise to the development of the weathering crust in $\mathrm{Ha}$ Tri is characterized by, (i) obliteration of bedrock which resulted in dissolution and (ii) subsequent limonitization. During obliteration and dissolution stage, smectites form and incorporated with the chromium presumably released during primary minerals alteration. But, as the weathering proceeds mobile elements like magnesium and silicon are preferentially 
leached (Bonifacio et al., 1997), leaving less mobile elements, like iron, chromium and aluminum in the profiles and form substituted oxides such as goethite and gibbsite.

Coherently, we suggested that the leaching process of magnesium is attributed to the formation of nontronite depicted by XRD on the profile (see Figure 4). Presence of willemseite is in agreement with the results presented by Bosio et al. (1975) and Decarreau et al. (1987), who found nontronite in the Jacuba garnierite.

More detail analysis of samples filling fractures, featureless voids, and cavities or as interstitial veins in the joints separating serpentine blocks in the lower part of the saprolite horizon, we discovered millerite, nepouite, spinel ferrian and magnesium-nickel silicate (Figure 5). Millerite is thought to form from sulfur and nickel which exist in pristine olivine in trace amounts, and which are driven out of the olivine during metamorphic processes; it is commonly a supergene enrichment of $\mathrm{Ni}$ in secondary sulfides at the base of the profile (Butt \& Nickel, 1981). Besides millerite, the mineral aggregate in samples consists members of garnierite group (e.g. Brindley and Hang, 1973; Springer, 1974; Pelletier, 1983). These minerals can be formed by different combinations of the three main $\mathrm{Mg}-\mathrm{Ni}$ solid solutions with serpentine, talc, and sepiolite-like structures; clays (chlorites and smectites) being absent (Wells et al., 2009; Tauler et al., 2009; Villanova-deBenavent et al., 2011a). Often, they have been removed from their original emplacement and have accumulated in cavities, forming breccias (Cluzeland Vigier, 2008). The most common and most studied occurrences of garnierites are found in the less serpentinized ophiolite-related peridotites of mantle origin as in New Caledonia (Trescases, 1975; Wells et al., 2009) and in the Caribbean (Gleeson et al., 2003; Lewis et al., 2006).

The progressive enrichment of $\mathrm{Ni}$ in the saprolite horizon occurs by means of two dif- ferent processes. The dominant process is the direct replacement of pre-weathering minerals, such as olivine and serpentine, by $\mathrm{Ni} \mathrm{Fe}-$ enriched lizardites and by Ni-rich smectites. In the minerals formed by replacement, $\mathrm{Fe}$ and $\mathrm{Ni}$ increase at a percentage range (see $\mathrm{Ta}-$ bles and plots in Figure 5). The second process involves the precipitation of Mg-Ni phyllosilicates (Al-free garnierites) from aqueous solution. As described above, the garnierites form as fracture fillings, veins, and breccias. In contrast to the minerals formed by replacement, the garnierites are characterized by low $\mathrm{Fe}$ and are essentially free of $\mathrm{Al}$. These garnierite minerals and the conditions of the precipitation process by which they form are the occurrences of supergene enrichment of nickel.

Here we may propose three related, simultaneous phenomena: (1) supergene enrichment of $\mathrm{Ni}$ in a group of secondary phyllosilicates precipitating in Ni-laterite profile were found to be very helpful for this; (2) simultaneous precipitation of $\mathrm{Mg}$-Ni-phyllosilicate solid solutions; and (3) the spatial and temporal evolution of garnierites towards more silica-rich members, from serpentine to talc and sepiolite-type minerals, as has been described previously (e.g. Golightly, 1981; Freyssinet et al., 2005). A simplified chemical system which is useful in the description of the stability relations among the Ni-containing phyllosilicate phases consists of four components: $\mathrm{MgO}$, $\mathrm{NiO}, \mathrm{SiO}_{2}$, and $\mathrm{H}_{2} \mathrm{O}$. For aqueous solution the basic species are $\mathrm{Mg}^{2+}, \mathrm{Ni}^{2+}, \mathrm{SiO}_{2}(\mathrm{aq}), \mathrm{H}^{+}$, and $\mathrm{H}_{2} \mathrm{O}$. As garnierites are Fe-poor $(<0.5$ wt. $\%$ $\mathrm{Fe}$ ) indicating a secondary origin (Pelletier, 1983; Manceau and Calas, 1985; Manceau et al., 1985; Proenza et al., 2008; Wells et al., 1999), Fe was not included in the system. Its inclusion would increase the complexity of the system without affording significant new information regarding the distribution of $\mathrm{Ni}$ among the main phases present. After weathering, residual $\mathrm{Fe}$ of the parent rock is concen- 
trated in a highly insoluble limonitic horizon, formed mainly of goethite, hematite, and maghemite. This horizon is best defined by the

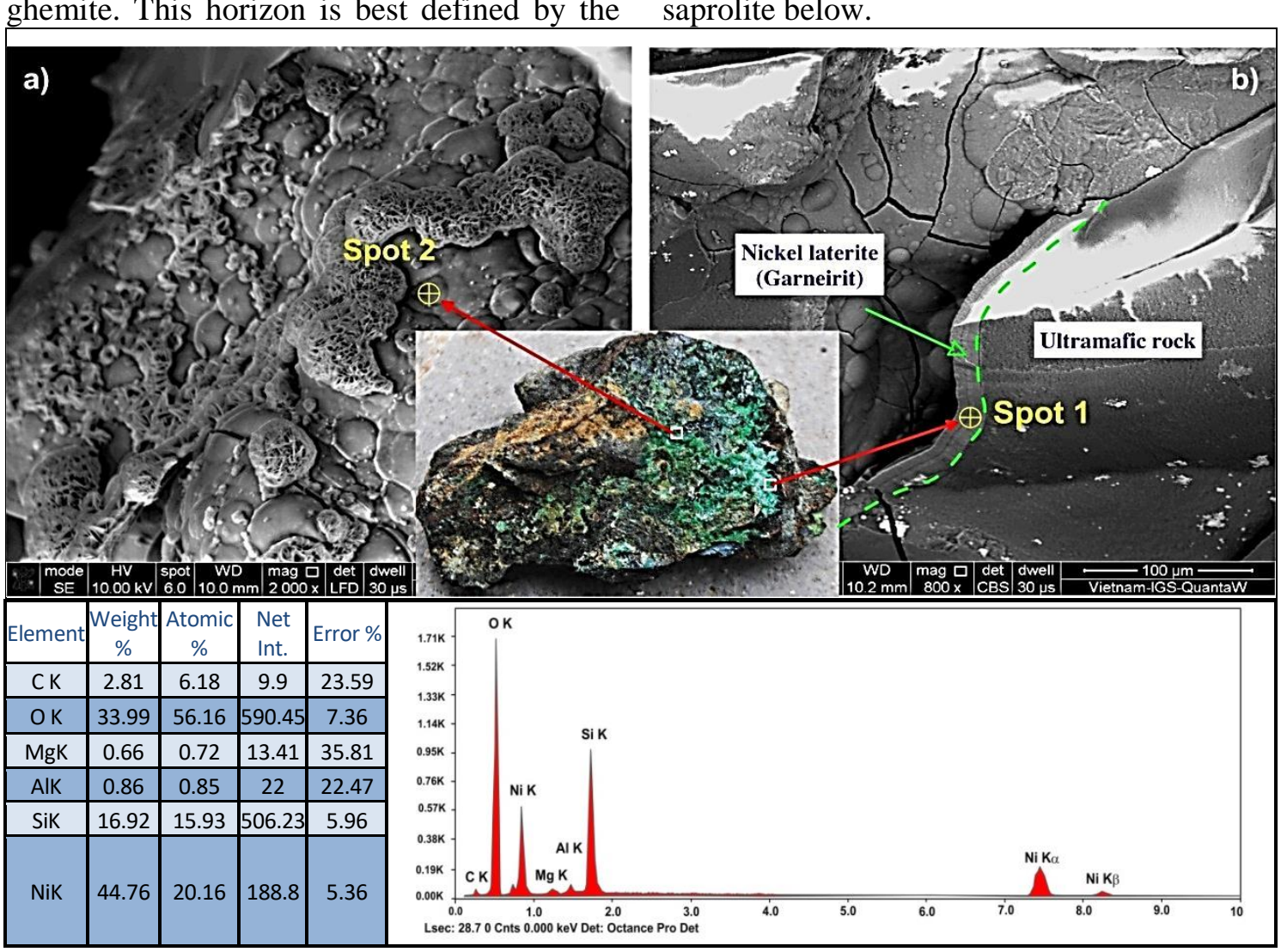

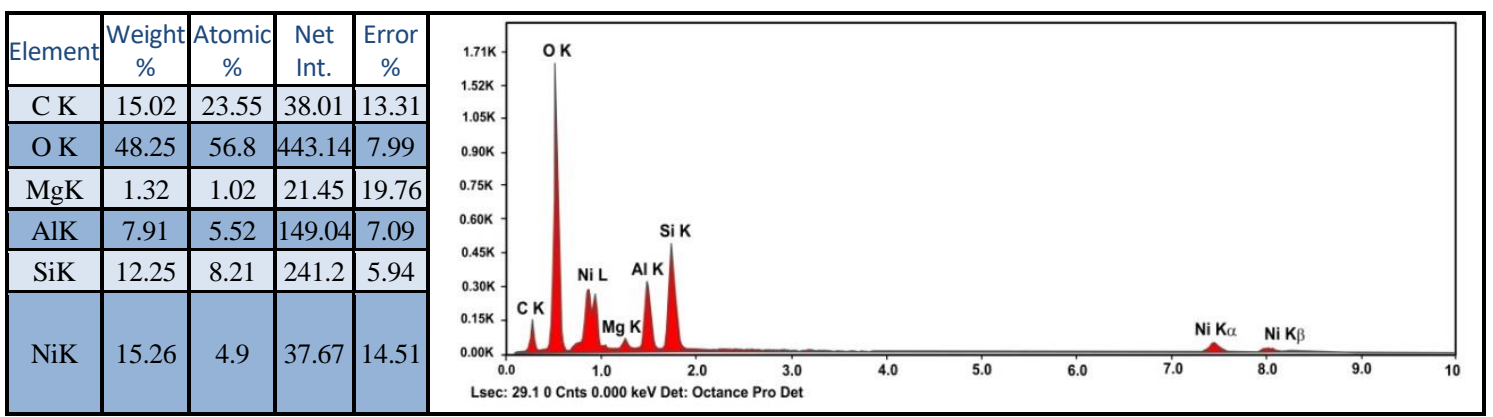

Figure 5. Scanning electron microscope (SEM) photomicrographs and approximately chemical composition of twopoints: (a) in cavity rims and (b) in the surface of crack (b) in saprolite horizon of Ha Tri weathering profile.

$\mathrm{Ni}$ contents in both two points are high

The SEM analyses plotted in Figure 6 show post-serpentinization process results in replacement of magnesium by nickel. The magnesium replacement process could be attributed to ionic exchange reaction such as
$\mathrm{Mg}$ serpentine $+\mathrm{Ni}^{2+}=\mathrm{Ni}$-rich serpentine + $\mathrm{Mg}^{2+}$. This process leads to enrichment of $\mathrm{Ni}$ and depletion of $\mathrm{Mg}$ in the saprolite horizon, which can be seen in the results of SEM analysis (Figure 6). Subsequent to the dissolution 
process is the limonitization, which involve crystallization of $\mathrm{Fe}$ oxyhydroxides (e.g, goethite and hematite) dominant in the overlying limonite horizon at Ha Tri. According to Becquer et al. (2006) and Garrnier et al. (2006), aluminum, chromium, and nickel released during the weathering of primary minerals can be incorporated into iron oxides. This oxiderich portion of the profile is referred to informally as limonite and the volume of the upper collapsed portion may be as little as $\sim 15 \%$ of the original rock (Golightly, 1981).
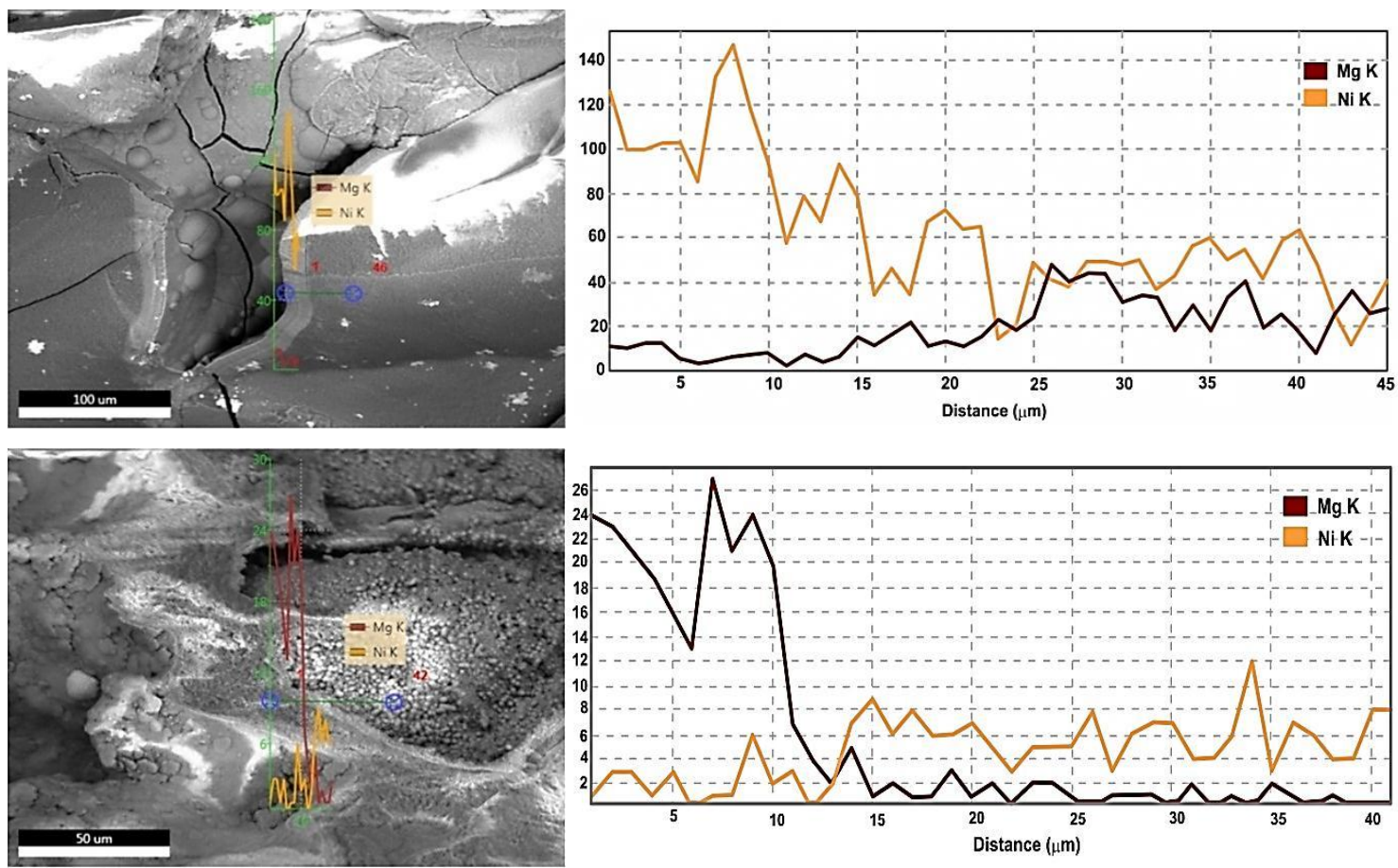

Figure 6. The linear scanning electron microscope photomicrographs of cavity rims in saprolie horizon of Ha Tri weathering profile. The opposite variation in $\mathrm{Mg}$ and $\mathrm{Ni}$ contents is an evident of replacement of $\mathrm{Mg}-\mathrm{Ni}$ in solidsolution of Mg-Ni-phyllosilicates extending from $\mathrm{Mg}$ and $\mathrm{Ni}$ end members

The Mg-Ni-phyllosilicates are members of three solid-solution series extending from $\mathrm{Mg}$ and $\mathrm{Ni}$ end members (e.g. Springer, 1974, 1976; Brindley et al., 1979; Gleeson et al., 2003; Tauler et al., 2009; Wells et al., 2009; Reddy et al., 2009; Villanova-de-Benavent et al., 2011b). The stable solid solution between $\mathrm{Mg}$ and $\mathrm{Ni}$ end-members in the structures of these minerals must be possible at atmospheric temperatures and pressure. Therefore, a complete solid solution between $\mathrm{Mg}$ and $\mathrm{Ni}$ end-members is a reasonable hypothesis. The terminology used here for the end-members, composition, and structure for the solid solu- tions are: serpentine $\left(\mathrm{Mg}_{3} \mathrm{Si}_{2} \mathrm{O}_{5}(\mathrm{OH})_{4}\right)$, nespouite $\left(\mathrm{Ni}_{3} \mathrm{Si}_{2} \mathrm{O}_{5}(\mathrm{OH})_{4}\right)$; kerolite (or hydrated talc) $\left.\quad \mathrm{Mg}_{3} \mathrm{Si}_{4} \mathrm{O}_{10}(\mathrm{OH})_{2} \cdot \mathrm{H}_{2} \mathrm{O}\right)$, pimelite (or hydrated willemseite) $\left(\mathrm{Ni}_{3} \mathrm{Si}_{4} \mathrm{O}_{10}(\mathrm{OH})_{2} \cdot \mathrm{H}_{2} \mathrm{O}\right)$; and sepiolite $\left.\left(\mathrm{Mg}_{8} \mathrm{Si}_{12} \mathrm{O}_{30} \mathrm{OH}\right)_{4}\left(\mathrm{H}_{2} \mathrm{O}\right)_{4} \cdot 8 \mathrm{H}_{2} \mathrm{O}\right)$ falcondoite $\left(\mathrm{Ni}_{8} \mathrm{Si}_{12} \mathrm{O}_{30} \mathrm{OH}\right)_{4}\left(\mathrm{H}_{2} \mathrm{O}\right)_{4} \cdot 8 \mathrm{H}_{2} \mathrm{O}$ ) (Brindley and Hang, 1973; Brindley and Maksimovic, 1974; Springer, 1974; Brindley and Wan, 1975; Brindley et al., 1979).

\section{Conclusions}

The lateritic weathering crust developed at Ha Tri, Cao Bang, is broadly similar to sapro- 
lite nickel laterite deposits around the world. The mineralogical and geochemical process which affected the ultramafic bedrock of Cao Bang complex and gave rise to the weathering crust in Suoi Cun is characterized by obliteration and dissolution of bedrock followed by limonitization. The Ni enrichment in Ha Tri is inferred to be attributed to percolation of surface solutions and the result of an ionic exchange reaction as:

$\mathrm{Mg}$ serpentine $+\mathrm{Ni}^{2+}=\mathrm{Ni}$-rich serpentine $+\mathrm{Mg}^{2+}$

With pronounced weathering, all relicts of bedrock and saprolite were obliterated and the limonite zone was formed. Therefore, we suggest that following the dissolution processes limonitization where iron oxides (goethite in particular) are dominant in the overlying limonite horizon at Ha Tri. In the upper part of the profile, leaching of $\mathrm{Mg}$ favored formation of nontronite. Nickel is a marker in the various horizons and appears in various mineral associations; generally with iron oxides (mainly as goethite) defining the limonitic zone, unclear association with smectite (nontronite) and with serpentine in the saprolitic horizons.

Significant nickel enrichments are very partial in limonite zones but are chiefly developed in the saprolite zone indicating water movement through these zones downward to a very low water table, meaning much of the nickel in Suoi Cun profile percolated downwards and reprecipitated in the saprolite zones. Nickel content decreases upward the weathering profile and it is removed during the recrystallization of goethite and the leaching of manganese oxide phases. Crystallization of iron oxide in the form of goethite often has the low capacity for nickel fixation. This could also allow easy capture of the metal by percolating down water from the limonitic horizon and redeposited in the saprolitic region at Suoi Cun. Conversely, nickel in Suoi Cun has been substituting $\mathrm{Mg}$ in altered silicate during the earlier phases of the weather- ing, incorporated as concretions with other elements, leached from the limonite concretions, moves down the profile under the influence of gravitated percolating water, and finally redeposited in the saprolite zone, hosted by hydrous silicates. The presence of the hydrous silicate type (minerals of garnierite group) at the lower saprolite horizon in weathering profile are evidence of supergene nickel ore.

\section{Acknowledgements}

This article is the product of the State research project, Code KHCN-TB-02T/13-18 under the State Program of ScienceTechnology for Sustainable Development of the Northwestern Region. Many thanks for the technical support provided by the Institute of Geology, VAST.

\section{References}

Bonifacio E., Zanini E., Boero V., Franchini Angela M., 1997. Pedogenesis in a soil catena on serpentine in north-western Italy. Geoderma, 75, 33-51.

Bosio N.J., Hurst J.V., Smith R.L., 1975. Nickelliferousnontronite, a $15 \AA$ garnierite, at Niquelandia, Goias Brazil. Clays Clay Miner., 23, 400-403.

Brand N.W., Butt C.R.M., Elias M., 1998. Nickel Laterites: Classification and features. AGSO Journal of Australian Geology \& Geophysics, 17(4), 81-88.

Bricker O.P., Nesbitt H.W. and Gunter W.D., 1973. The stability of talc. American Mineralogist, 58, 64-72.

Brindley G.W. and Hang P.T., 1973. The nature of garnierites. Structures, chemical composition and color characteristics. Clay and Clay Minerals, 21, 27-40.

Brindley G.W. and Maksimovic Z., 1974. The nature and nomenclature of hydrous nickel-containing silicates. Clay Minerals, 10, 271-277.

Brindley G.W. and Wan H.M., 1975. Composition structures and thermal behavior of nickel containing minerals in thelizardite-ne' pouite series. American Mineralogist, 60, 863-871.

Brindley G.W., Bish D.L. and Wan H.M., 1979. Compositions, structures and properties of nickel containing minerals in the kerolite-pimelite series. American Mineralogist, 64, 615-625. 
Nguyen Van Pho, et al./Vietnam Journal of Earth Sciences 40 (2018)

Cluzel D. and Vigier B., 2008. Syntectonic mobility of supergene nickel ores from New Caledonia (Southwest Pacific). Evidence from faulted regolith and garnierite veins. Resource Geology, 58, 161-170.

Colin F., Nahon D., Trescases J.J., Melfi A.J., 1990. Lateritic weathering of pyroxenites at Niquelandia, Goais, Brazil: The supergene behavior ofnickel: Economic Geology, 85, 1010-1023.

Das S.K., Sahoo R.K., Muralidhar J., Nayak B.K., 1999. Mineralogy and geochemistry of profilesthrough lateritic nickel deposits at Kansa,Sukinda, Orissa. Joural of Geoogical. SocietyIndia, 53, 649-668.

Decarreau A., Colin F., Herbillon A., Manceau A., Nahon D., Paquet H., Trauth-Badaud D.,Trescases J.J., 1987. Domain segregation in NiFe-Mg-Smectites. Clay Minerals, 35, 1-10.

Freyssinet P., Butt C.R.M. and Morris R.C., 2005. Oreforming processes related to lateritic weathering. Economic Geology, 100 ${ }^{\text {th }}$ aniversary volume, 681722.

Garnier J., Quantin C., Martins E.S., Becquer T., 2006. Solid speciation and availability of chromium in ultramafic soils from Niquelandia, Brazil. Journal of Geochemical Exploration, 88, 206-209.

Garnier J., Quantin C., Guimarães E., Becquer T., 2008. Can chromite weathering be a source of $\mathrm{Cr}$ in soils? Mineralogy Magazine, 72, 49-53.

Gleeson S.A., Butt C.R. and Elias M., 2003. Nickel laterites: A review. SEG Newsletter, 54, 11-18.

Gleeson S.A., Butt C.R., Wlias M., 2003. Nickellaterites: a review. SEG Newsletter, Society of Economic Geology, 54. Available from www.segweb.org.

Golightly J.P., 1981. Nickeliferous laterite deposits. Economic Geology, 75th Anniversary volume, 710-735.

Golightly J.P., 2010. Progress in understanding the evolution of nickel laterite. Society of Economic Geology, In Special Publication, 15, 451-485.

Manceau A. and Calas G., 1985. Heterogeneous distribution of nickel in hydrous silicates from New Caledonia ore deposits. American Mineralogist, 70, 549-558.

Nguyen Van Pho, 2013. Tropic weathering in Vietnam (in Vietnamese). Pubisher Science and Technology, $365 \mathrm{p}$.

Ngo Xuan Thanh, Tran Thanh Hai, Nguyen Hoang, Vu Quang Lan, S. Kwon, Tetsumaru Itaya, M. Santosh, 2014. Backarc mafic-ultramafic magmatism in
Northeastern Vietnam and its regional tectonic significance. Journal of Asian Earth Sciences, 90, 45-60.

Pelletier B., 1983. Localisation du nickel dans les minerais "garnieritiques" de Nouvelle-Caledonie. Sciences Ge'ologique: Me'moires, 73, 173-183.

Pelletier B., 1996. Serpentines in nickel silicate ores from New Caledonia. In Grimsey E.J., and Neuss I. (eds): Nickel '96, Australasian Institute of Miningand Metallurgy, Melbourne, Publication Series 6(9), 197-205.

Proenza J.A., Lewis J.F., Galí S., Tauler E., Labrador M., Melgarejo J.C., Longo F. and Bloise G., 2008. Garnierite mineralization from Falcondo Ni-laterite deposit (Dominican Republic). Macla, 9, 197-198.

Soler J.M., Cama J., Galí S., Meléndez W., Ramírez, A., and Estanga, J., 2008. Composition and dissolution kinetics ofgarnierite from the Loma de Hierro Ni-laterite deposit, Venezuela. Chemical Geology, 249, 191-202.

Springer G., 1974. Compositional and structural variations ingarnierites. The Canadian Mineralogist, 12, 381-388.

Springer G., 1976. Falcondoite, nickel analogue of sepiolite. The Canadian Mineralogist, 14, 407-409.

Svetlitskaya T.V., Tolstykh N.D., Izokh A.E., Phuong Ngo Thi, 2015. PGE geochemical constraints on the origin of the Ni-Cu-PGE sulfide mineralization in the Suoi Cun intrusion, Cao Bang province, Northeastern Vietnam. Miner Petrol, 109, 161-180.

Tran Trong Hoa, Izokh A.E., Polyakov G.V., Borisenko A.S., Tran Tuan Anh, Balykin P.A., Ngo Thi Phuong, Rudnev S.N., Vu Van Van, Bui An Nien, 2008. Permo-Triassic magmatism and metallogeny of Northern Vietnam in relation to the Emeishan plume. Russ. Geol. Geophys., 49, 480-491.

Tri T.V., Khuc V. (eds), 2011. Geology and Earth Resources of Vietnam. Publishing House for Science and Technology, 645p (in English).

Villanova-de-Benavent C., Proenza J.A., Galí S., Tauler E., Lewis J.F. and Longo F., 2011. Talc- and serpentine-like "garnierites" in the Falcondo Ni-laterite deposit, Dominican Republic. 'Let's talk ore deposits', $11^{\text {th }}$ Biennial Meeting SGA 2011, Antofagasta, Chile, $3 p$.

Wells M.A., 2003. Goronickel laterite deposit. New Caledonia. CRC LEME, 3p. 